\title{
Cyclic Adenosine Monophosphate-Dependent Protein Kinase in Adipose Tissue of Newborn Infants
}

\author{
PAUL B. WIESER, ${ }^{(25)}$ MILAN NOVAK, MARIA BUCH, AND JOSEF P. SKALA ${ }^{(24)}$ \\ Department of Pediatrics, University of Miami School of Medicine, Miami, Florida, USA and Centre for \\ Developmental Medicine, University of British Columbia, Vancouver, British Columbia, Canada
}

\begin{abstract}
Summary
The rate of histone phosphorylation in adipose tissue abstracts obtained from adults and newborns by cyclic adenosine monophosphate (cAMP)-dependent protein kinase was studied. Adensine triphosphate (ATP) had an apparent $\mathrm{Km}$ of $0.18 \mu \mathrm{M}$. Further kinetic studies indicated that human white adipose tissue is similar to brown adipose tissue of newborn rats in that it probably contains more than one type of soluble cyclic AMP-dependent protein kinase activity.

Cyclic AMP activated the human enzyme with maximum velocity reached at $1 \mu \mathrm{M}$ concentration. Cyclic guanosine monophosphate, however, produced only a low level activation of the enzyme, perhaps more dose-dependent when arginine-rich histone served as the phosphate acceptor.

The activity in samples of subcutaneous adipose tissue of two age groups of healthy newborns was compared with samples obtained from adult volunteers. Both the basal activity and the cAMP-activated enzymes showed an increase with age. The velocity values for the rate of phosphorylation observed in the presence of relatively high $\mathrm{NaCl}$ concentrations were depressed by approximately $50 \%$; the "activity ratio" under these conditions, however, reflected the true in vivo state of activation of the type II protein kinase.

It has been confirmed by a series of methodologic experiments that the cyclic AMP dependent protein kinase of adult human white fat exhibits the same properties as the type II enzyme described in rat white adipose tissue. The activity ratio was determined on samples of subcutaneous adipose tissue of different age groups of healthy human newborns and of adult volunteers. The system is highly activated immediately after birth (less than $12 \mathrm{hr}$ ) and a subsequent decrease $(12-48 \mathrm{hr})$ in the level of activation is observed.
\end{abstract}

\section{Speculation}

The protein kinase system, its composition, characteristics, and in particular, its level of activation under physiologic and pathologic conditions is of utmost importance in our understanding of the molecular mechanisms of hormonal regulation occurring in infant adipose tissue. Experimental conditions described here allow determinations of the in vivo level of activation of the cyclic AMP-dependent system and after further modification may help to link specific hormonal stimulation with phosphorylation, and, thus, functional changes, occurring in specific intracellular proteins.

The protein kinase system is the only intracellular system known to be dependent on cyclic nucleotides for expression of its activity. It "translates" the increased rate of cyclic AMP synthesis, occurring upon adenylate cyclase stimulation by a hormone, into the ultimate effect of such a stimulation by introducing a phosphoryl group into a protein molecule. Such phosphorylation, combined with dephosphorylation catalyzed by phosphoprotein phosphatases, is known to occur concurrently with activity changes in a variety of hormone-mediated regulatory processes (13). Hence, the protein kinase system, its composition, characteristics, and, in particular, its level of activation under physiologic and pathologic conditions, is of utmost importance in understanding the molecular mechanisms of hormonal regulation.

Hormones in general, and catecholamines in particular, are known to directly control the metabolism of subcutaneous white adipose tissue of mammalian newborns, including human infants (9). It has been shown repeatedly that the metabolic changes occurring in adipose tissue of human newborns immediately after birth contribute significantly to the adaptive mechanisms necessary for the neonate to cope with the extrauterine environment (11). Brown adipose tissue has been studied in great detail in neonatal mammals in this respect $(6,16,18-20)$, but information on molecular mechanisms participating in hormonal regulation of white adipose tissue metabolism during the neonatal period, particularly in humans, is still rather scarce.

It has been shown that lipolytic agents, capable of increasing the intracellular levels of cyclic AMP, can activate the cyclic AMP-dependent protein kinase in white adipose cells (14). The activated enzyme then catalyzes the transfer of the terminal phosphoryl group from ATP to serine and threonine residues of hormone-sensitive lipase; this process causes the lipase to be converted to an active form (5). Similar activation by phosphorylation occurs in the phosphorylase b kinase-phosphorylase system and the reverse is true for the glycogen synthetase system (5). Both lipolysis and glycogenolysis are increased in adipose tissue of newborns (12). It has been suspected, but never directly proved, that the activation of a cyclic AMP-dependent protein kinase is involved. We have, therefore, decided to initiate studies of the protein kinase system in subcutaneous white adipose tissue of human newborns.

Cyclic AMP-dependent protein kinase in white fat, like that in other tissues, consists of regulatory and catalytic subunits (2). When cyclic AMP binds to the regulatory subunit, it causes the holoenzyme to dissociate and release the catalytic activity; reassociation of the subunits and, thus, inactivation occurs upon the removal of the cyclic nucleotide (2). Corbin et al. (1) established conditions under which the proportion of active catalytic subunits and inactive holoenzyme is not altered in white fat of adult rats during tissue preparation and homogenization. An accurate estimate of the state of activation of the protein kinase in vivo is, thus, possible. We have confirmed that the conditions used by Corbin et al. (1) can be applied to human tissue and have investigated the degree of activation of protein kinase in the immediate postparturition period. Some more detailed time sequence studies of the kinase activation ratio (activity-cAMP/activity + cAMP) were 
performed on brown adipose tissue of newborn rats to complement the data obtained on humans.

\section{MATERIALS AND METHODS}

\section{SAMPLE PREPARATION}

Samples of infant subcutaneous adipose tissue were obtained by a needle biopsy technique (10). Written informed consent for these samples was obtained (25). Due to the small amount of material obtained by this method $(10-30 \mathrm{mg})$, some samples of adult human adipose tissue (2-5 g) obtained during elective surgery (tubal ligation performed under epidural anaesthesia) were used to establish the assay conditions. Samples of rat (Wistar, Woodlyn Laboratories, Guelph, Ontario) brown adipose tissue (25-80 mg depending on age) were obtained after decapitation from the cervical and interscapular regions of infant animals from timed pregnancies. All samples were rapidly frozen in liquid nitrogen and stored at $-80^{\circ}$ until assayed. Storage of up to $2 \mathrm{wk}$ did not result in any loss of activity or change in the protein kinase ratio.

Samples were homogenized in 5 volumes of ice-cold $4 \mathrm{mM}$ EDTA, pH 7.0 using a glass Potter-Elvehjem homogenizer fitted with a motor-driven Teflon pestle. The homogenates were centrifuged at $20,000 \times g$ for $30 \mathrm{~min}$ and the supernatants assayed immediately for protein kinase activity. In the studies of the protein kinase activation ratio, the isolation medium consisted of $0.5 \mathrm{M} \mathrm{NaCl}, 10 \mathrm{mM}$ EDTA, $10 \mathrm{mM}$ theophylline, and $10 \mathrm{mM}$ potassium phosphate, $\mathrm{pH} 6.5$ and the sample preparation step was timed not to exceed $40 \mathrm{~min} \pm 3$ between the thawing of the tissue and the start of the assay. Detailed information on the technique is published elsewhere (19).

\section{ENZYMIC ASSAYS}

The protein kinase assays were performed as previously described (17). Ten $\mu \mathrm{l}$ of the sample containing 5-30 $\mu \mathrm{g}$ of protein was used to start the assay. Protein was assayed by the method of Lowry et al. (8). $\left({ }^{32} \mathrm{P}\right) \mathrm{ATP}$ was prepared by the method of Glynn and Chappell (3) from $\left({ }^{32} \mathrm{P}\right)$ phosphoric acid. Nonlabeled nucleotides, histones, and other chemicals were purchased from Sigma Chemical Co., St. Louis, Mo., and were of highest purity commercially available.

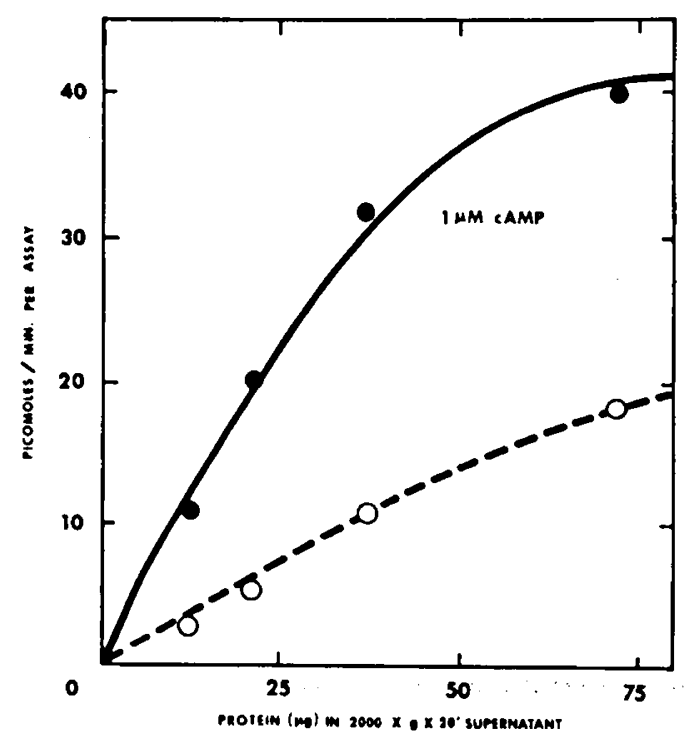

Fig. 1. Effect of protein concentration on protein kinase activity. Adipose tissue of human adults was homogenized in $4 \mathrm{mM}$ EDTA, centrifuged at $20,000 \times g$ for $30 \mathrm{~min}$ and the supernatant assayed for protein kinase activity in the absence and presence of $1 \mu \mathrm{M}$ cyclic AMP.

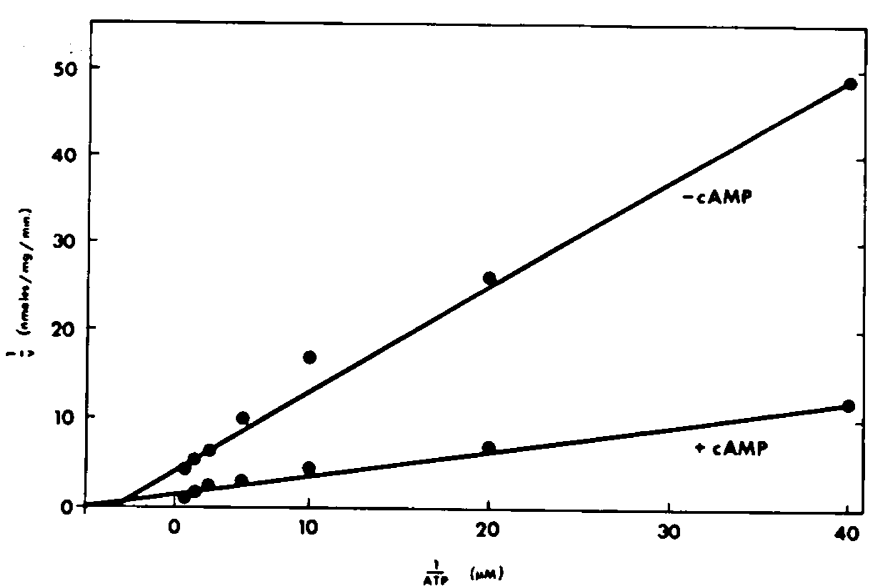

Fig. 2. Effect of ATP concentration on protein-kinase activity in white adipose tissue of human adults. Double reciprocal plot of ATP concentration vs. velocity. From the plot, the apparent $\mathrm{Km}$ for ATP was calculated to be $0.18 \mu \mathrm{M}$.

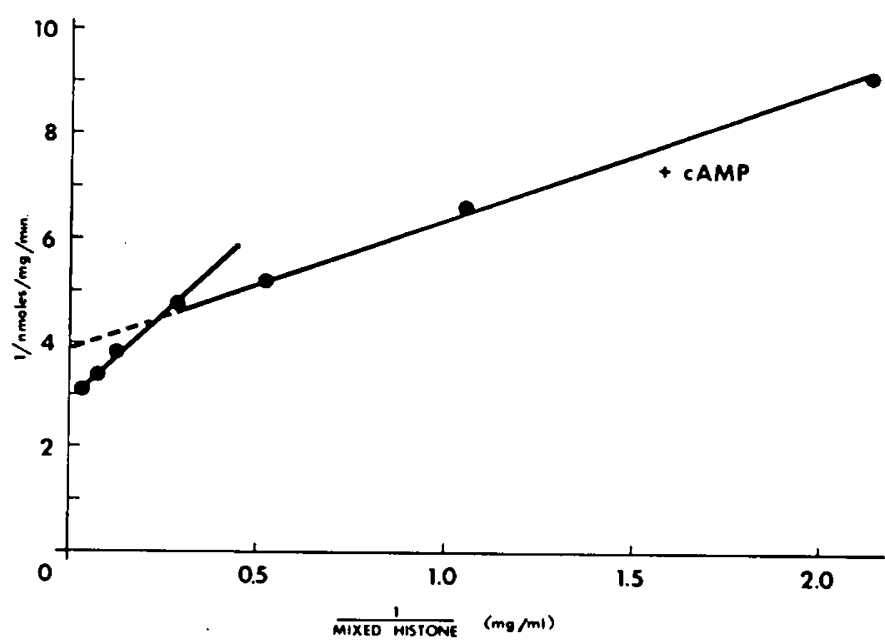

Fig. 3. Effect of histone (II-A) concentration on protein kinase activity in soluble extracts of human adult white fat. Double reciprocal plot of histone IIA concentration $v s$. velocity in the presence of cyclic AMP.

\section{RESULTS}

The rate of histone phosphorylation with the crude extracts of adult human adipose tissue was linear with time up to $30 \mathrm{~min}$ and with amount of sample up to $40 \mu \mathrm{g}$ of protein (Fig. 1). Sample protein content of $10-30 \mu \mathrm{g}$ and incubation time of $20 \mathrm{~min}$ at $30^{\circ}$ were selected for subsequent assays. Simple saturation kinetics with respect to ATP was observed. When the reciprocals of ATP concentration were plotted against the reciprocal values of velocity (Fig. 2), an apparent $\mathrm{Km}$ of $0.18 \mu \mathrm{M}$ was observed. When the velocity of the reaction was plotted against the histone (mixed, type IIA) concentration (Fig. 3), a double-sloped correlation emerged. It was even more apparent (Fig. 4) with arginine-rich histone (Sigma type VIII), and was probably due to the presence in the crude extracts of more than one kinase activity with different affinities for the histone used. White adipose tissue of the human adult, thus, seems similar in that respect to brown adipose tissue of newborn rats (6) inasmuch as it probably contains more than one type of soluble protein kinase activity:

Cyclic AMP activated the human enzyme in a dose-dependent manner with both mixed histone (left upper panel of Fig. 5) and arginine-rich histone (left lower panel of Fig. 5) as substrates, with a maximum activation reached at $1 \mu \mathrm{M}$. Cyclic GMP, however, produced only a low-level activation of the enzyme (right panels 


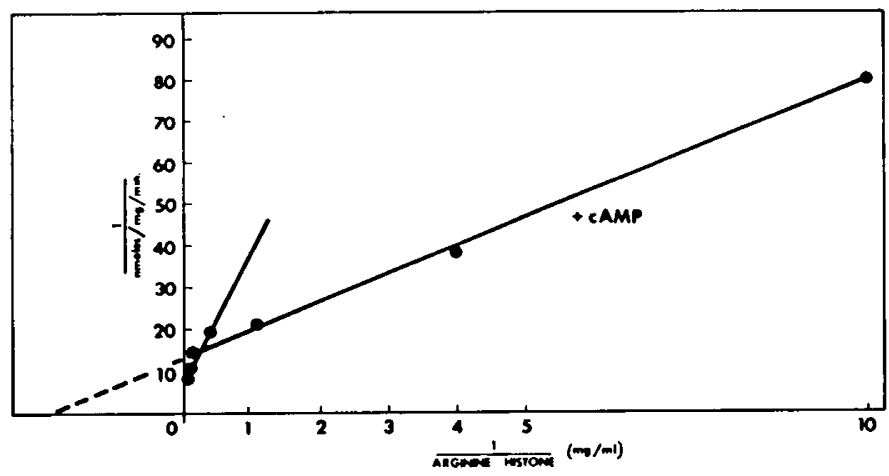

Fig. 4. Effect of arginine-rich histone concentration on protein kinase activity in soluble extracts of human adult white fat. Double reciprocal plot of arginine-rich histone concentration vs. velocity in the presence of cyclic AMP.

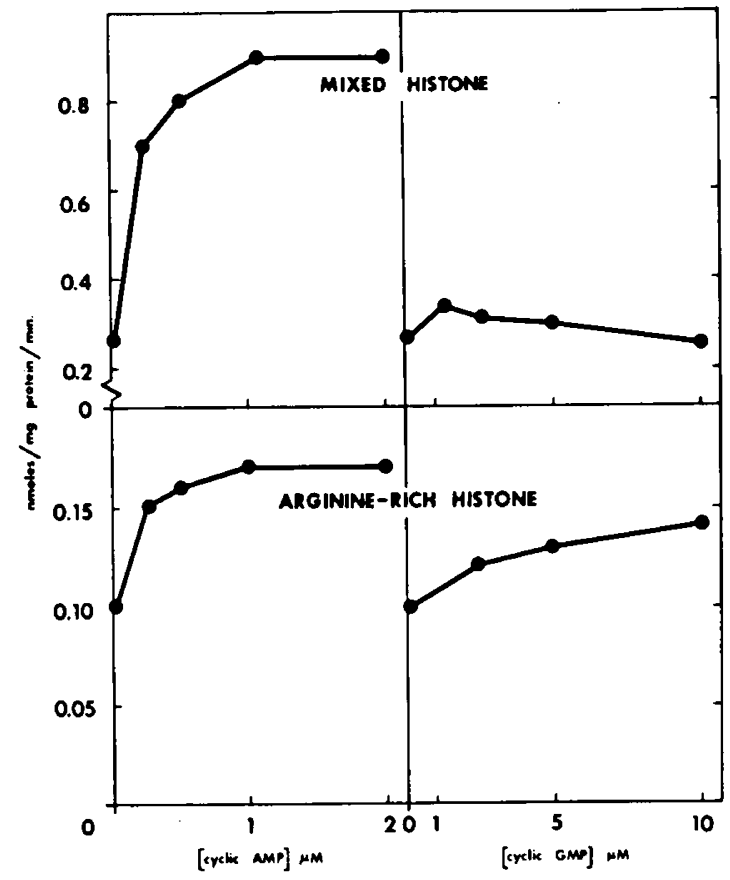

Fig. 5. Cyclic nucleotide specificity of adult human adipose tissue protein-kinase. Protein kinase was assayed with the indicated concentration of cyclic AMP and cyclic GMP with mixed or arginine-rich histone as substrate.

of Fig. 5), perhaps more dose-dependent when arginine-rich histone served as the phosphate acceptor.

Having thus established the optimal assay conditions and the basal characteristics of the protein kinase in crude extracts of human adult adipose tissue, we determined the activity in samples of subcutaneous adipose tissue of two age groups of healthy newborns and compared it with samples obtained from adult volunteers (Fig. 6). As shown, both the basal activity and the cAMP activated enzyme showed an increase with age.

In a system such as protein kinase, the state of activation in vivo is more physiologically relevant than the maximum activity assayed in vitro. Corbin et al. (1) has shown that the presence of high salt concentration in the isolation medium prevents the dissociation and reassociation of the subunits of the type II enzyme subsequent to the tissue collection. Higher salt concentration, however, exerts an inhibitory effect on the maximum velocity of the enzyme (19). As shown in Figure 7, this also proved to be the case for human adult adipose tissue protein kinase. The velocity values for the rate of phosphorylation observed in the presence of relatively high $\mathrm{NaCl}$ concentrations hence become artificially low; the activity ratio, however, reflects the true in vivo state of the type II protein kinase $(1,19)$. By using $0.5 \mathrm{M} \mathrm{NaCl}$ in the isolation medium, which becomes $0.1 \mathrm{M}$ in the assay medium, approximately $50 \%$ (Fig. 7) of the maximum velocity is detected.

In order to ensure that the $0.5 \mathrm{M} \mathrm{NaCl}$ indeed prevented the reassociation of the protein kinase subunits in human adult white fat, the following dilution experiment was performed: the kinase was fully activated in the crude extracts by the addition of $0.3 \mu \mathrm{M}$ cAMP and the cyclic nucleotide was subsequently removed by

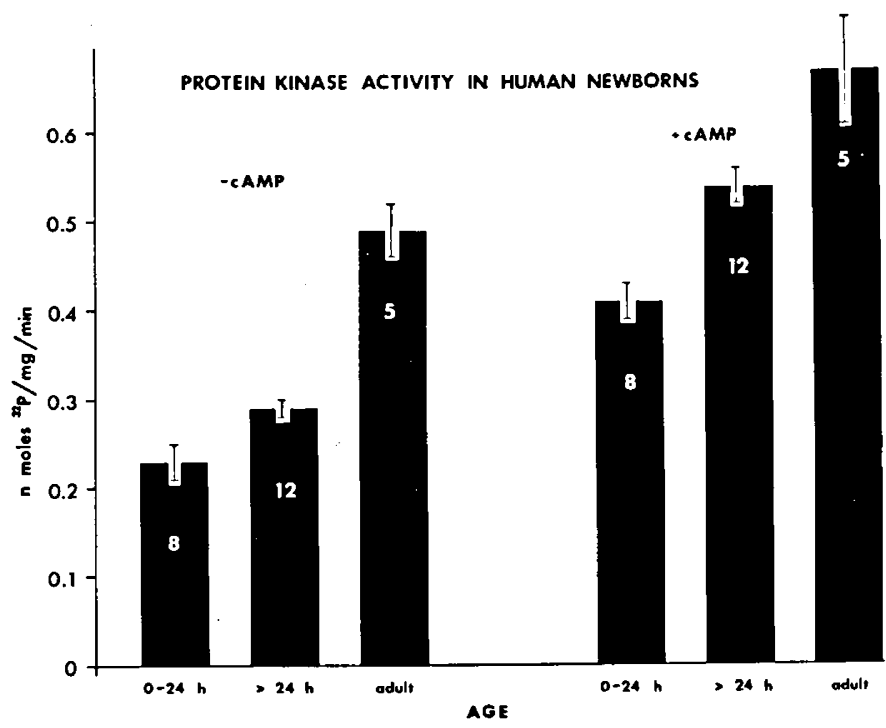

Fig. 6. Protein kinase activity in subcutaneous white adipose tissue of human newborns. The activity was determined in whole tissue homogenates of adipose tissue in the age range indicated. The data are the mean $\pm S E$ for duplicate determinations of the indicated number of samples.

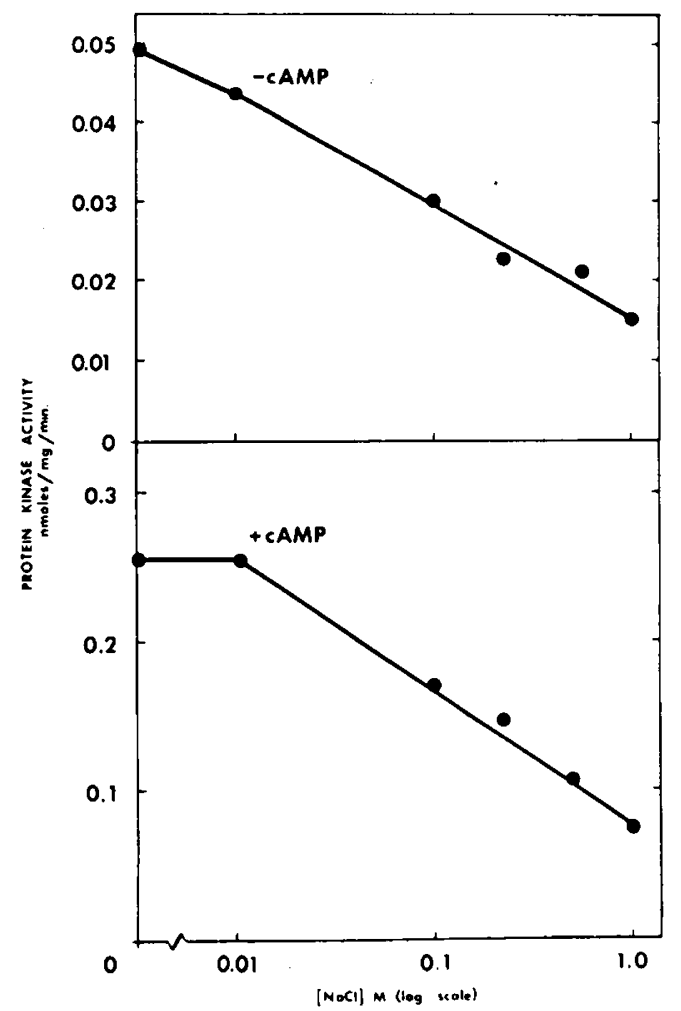

Fig. 7. Effect of sodium chloride on protein kinase activity in soluble extracts of human adult white adipose tissue. The activity was assayed in the presence of the indicated concentration of $\mathrm{NaCl}$. Cyclic AMP $(1 \mu \mathrm{M})$ was present where indicated. 


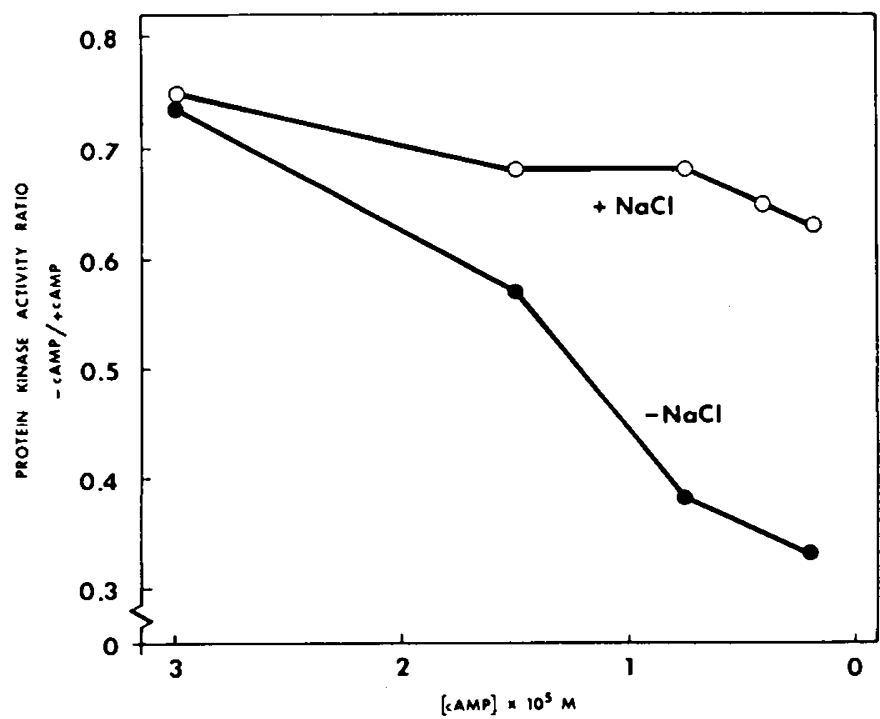

Fig. 8. Effect of $\mathrm{NaCl}$ on the reassociation of the protein kinase subunits in white fat of human adults. The adipose tissue soluble extract was incubated in the presence of $0.3 \mu \mathrm{M}$ cyclic AMP for $10 \mathrm{~min} . \mathrm{NaCl}(0.5 \mathrm{M})$ was added to one set of the samples; the other set served as a control. The samples were then diluted with buffer to give the final concentration of cyclic AMP indicated.

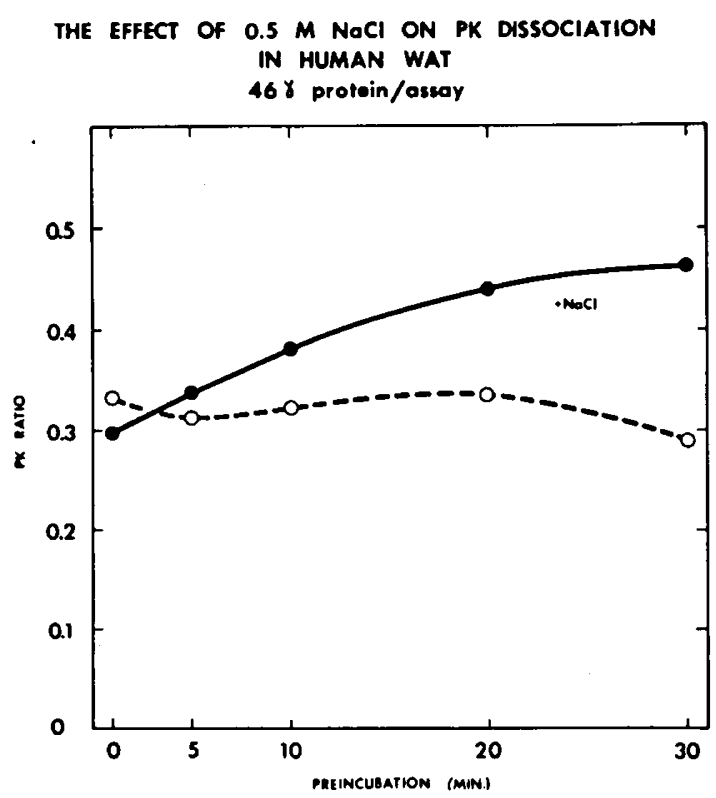

Fig. 9. The effect of histone on the dissociation of the protein kinase subunits both in the absence and the presence of $0.5 \mathrm{M} \mathrm{NaCl}$. Samples of supernatant fractions of adult human white fat were incubated at $30^{\circ}$ for $30 \mathrm{~min}$ in the presence of various concentrations of histone. At the end of incubation the assay medium (containing enough histone to bring the final concentration to $15 \mathrm{mg} / \mathrm{ml}$ ) was added and the activity ratio calculated after a 5 min assay for kinase activity with and without $1 \mu \mathrm{M}$ cAMP. $\mathrm{NaCl}$ $(0.5 \mathrm{M})$ was present where indicated.

serial dilutions of the sample by the isolation medium. This dilution resulted in a decrease of the basal activity whereas the activity assayed with cAMP remained the same, thus resulting in a gradually decreasing activity ratio (rate of phosphorylation observed in the absence of cAMP over that observed in the presence of $0.3 \mu \mathrm{M}$ cAMP) as shown in Figure 8 . When the same experiment was performed in the presence of $0.5 \mathrm{M} \mathrm{NaCl}$ in the isolation medium, the activity ratio remained high (Fig. 8), thus, indicating that the salt prevented reassociation of the protein kinase subunits. To ascertain that no dissociation was caused by the salt itself, we performed another series of experiments. Histone is known to activate the protein kinase by causing a gradual dissociation of the subunits (19). We have, therefore, preincubated the adult human fat supernatant samples for various lengths of time in the presence of low histone concentrations, and followed it with a 5-min assay of the activity. A slight dissociation (less than $20 \%$ after 30 min preincubation) of the subunits was actually lessened by the presence of $0.5 \mathrm{M} \mathrm{NaCl}$ (Fig. 9).

We have, thus, confirmed that the cyclic AMP-dependent protein kinase in adult human white fat exhibits the same properties as the type II enzyme according to the classification adopted by Corbin et al. Furthermore, we confirmed that in the presence of $0.5 \mathrm{M} \mathrm{NaCl}$ in the isolation medium the in vivo state of activation of the system is preserved. The activity ratio was then determined on samples of subcutaneous adipose tissue of different age groups of healthy human newborns and of adult volunteers. As shown in Figure 10, the system is activated immediately after birth and a subsequent decrease in the activation is observed. Samples from adult tissue showed a rather high degree of activation of the protein kinase system.

To complement the developmental data obtained on human white adipose tissue, we performed a series of determinations of the protein kinase activity ratio using brown adipose tissue of newborn rats. As shown in Figure 11, much more prominent changes in the activity ratio, spread over much shorter time intervals, were observed.

Finally, protein kinase activity and its activity ratio were compared in samples of subcutaneous white adipose tissue of nonpregnant and pregnant (36 wk of gestation) women. As shown in Table 1, both higher total activity and higher degree of activation was observed in the tissue of the pregnant group.

\section{DISCUSSION}

The presence in human adult white adipose tissue of a cyclic AMP-dependent protein kinase which activates the hormone sensitive lipase has previously been shown (14). We have assayed the enzyme in crude extracts of tissue from human newborns where hormone-mediated metabolic regulation is of particular importance (4). Protein kinase activity was estimated from the rate of histone phosphorylation. Both mixed histone and arginine-rich histone were readily phosphorylated with an apparent $\mathrm{Km}$ of 0.66 $\mathrm{mg} / \mathrm{ml}$ for the mixed histone. ATP served as the phosphate donor with an apparn $\mathrm{Km}$ of $0.18 \mu \mathrm{M}$. Cyclic GMP exhibited a much

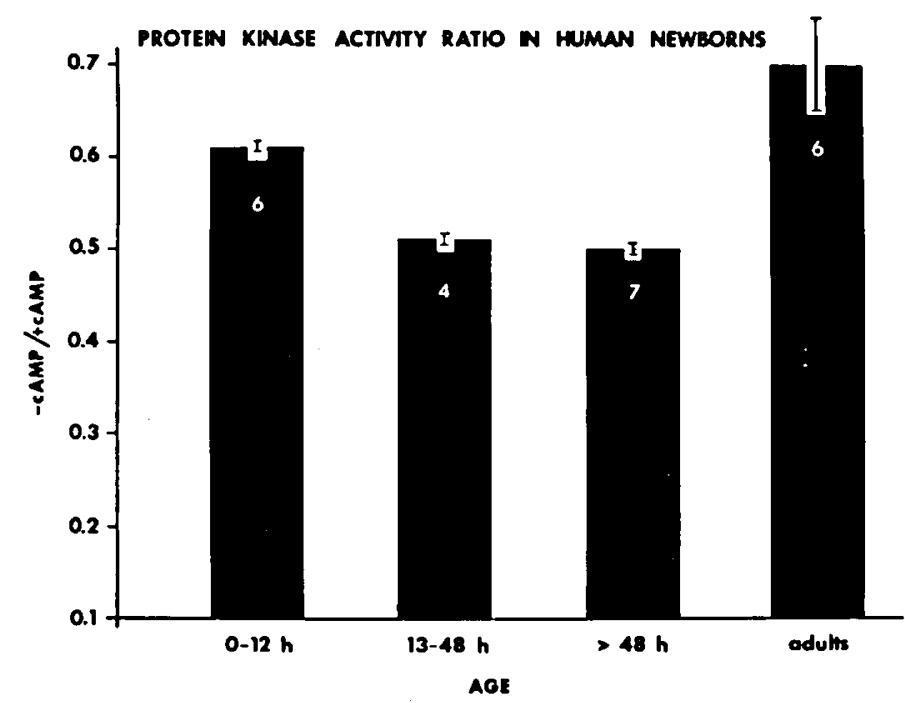

Fig. 10. Protein kinase activity ratios in human newborns. Protein kinase activity ratios, i.e., activity -cAMP/+cAMP were calculated from the data given in Figure 6 at the ages indicated. The data are the mean $\pm \mathrm{SE}$ for the given age ranges. 


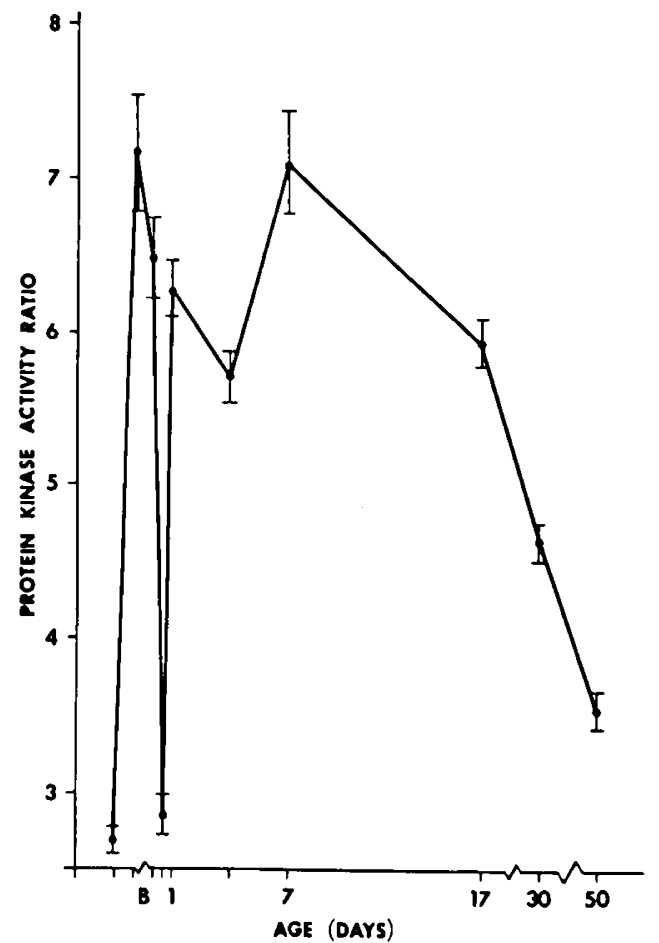

Fig. 11. Protein kinase activity ratios in newborn rats. Activity ratios were determined in brown adipose tissue of fetal, newborn, and older rats at the ages indicated. The data are the mean $\pm \mathrm{SE}$ for eight determinations on separate animals in each group.

Table 1. Protein kinase activity in normal and pregnant females ${ }^{1}$

\begin{tabular}{|c|c|c|c|}
\hline & \multicolumn{2}{|c|}{ Protein kinase activity } & \multirow{3}{*}{$\begin{array}{c}\begin{array}{c}\text { Activity } \\
\text { Ratio }\end{array} \\
\text {-cAMP/ } \\
\text { +cAMP }\end{array}$} \\
\hline & \multicolumn{2}{|c|}{ nmoles ${ }^{32} \mathrm{P}$ incorporated $/ \mathrm{mg} / \mathrm{min}$} & \\
\hline & -cAMP & +cAMP & \\
\hline $\begin{array}{l}\text { Normal } \\
\text { Pregnant }\end{array}$ & $\begin{array}{l}0.092 \pm 0.009 \\
0.154 \pm 0.030^{2}\end{array}$ & $\begin{array}{l}0.195 \pm 0.025 \\
0.267 \pm 0.038^{3}\end{array}$ & $\begin{array}{l}0.48 \pm 0.03 \\
0.57 \pm 0.03^{4}\end{array}$ \\
\hline
\end{tabular}

' Subcutaneous adipose tissue was obtained from female patients during delivery by caesarean section and patients undergoing tubal ligation (normal). The tissue was handled and assayed as described in the text. The data are the mean \pm SE for six duplicate determinations for each group. The activity ratio was calculated for each determination, and then subjected to systical analyses by Student's $t$ test.

${ }^{2} P<0.05$ compared to normal.

${ }^{3}$ Not significant.

${ }^{4} P<0.05$ compared to normal.

lesser degree of activation, more apparent with arginine-rich histone as substrate, which is in accord with Kuo's observations (7) on the cyclic GMP dependent protein kinase.

As previously pointed out for brown adipose tissue (19), the activity ratio of the protein kinase is more physiologically relevant than its maximum activity determined under in vitro conditions. Before the activation ratio can be used as a meaningful parameter, it is necessary to ascertain that the relative proportions of the inactive holoenzyme and the active catalytic subunits are not altered during sample preparation. The present results show that the addition of $0.5 \mathrm{M} \mathrm{NaCl}$ to the isolation medium inhibited the reassociation and did not initiate dissociation of the free kinase subunits in human white fat. Such an action of $\mathrm{NaCl}$ indicates that the cyclic AMP-dependent protein kinase in human adult white fat should be classified as a type II enzyme under the convention adopted by Corbin et al. (1).

The relationship between the protein kinase activity ratio and the intracellular concentration of cyclic AMP expressed in terms of simple saturation kinetics has been shown in brown adipose tissue of newborn rats (19). The activity ratio was also directly related to the rate of lipolysis observed under a variety of conditions. Our present data on white adipose tissue of newborn humans shows no evidence contradictory to our assumption that the human white adipose tissue protein kinase system carries out similar functions by similar mechanisms to that of brown fat of newborn mammals.

It is important to note that, even though the maximal total protein kinase activity observed during the immediate postparturition period was lower than that 2-3 days after birth, the activity ratio was higher during the first $12 \mathrm{hr}$ of life than later. This finding is consistent with reports that the rate of lipolysis in white fat of human newborns is high immediately after delivery and subsequently declines (12). Furthermore, this finding again underlines the importance of considering the activity ratio rather than the total activity of the protein kinase system when discussing the physiologic relevance of the data.

Using samples of interscapular brown adipose tissue of newborn rats made it possible to follow the protein kinase activity ratio at much shorter time intervals. The activity ratio increased by approximately $150 \%$ at the time of delivery, remained high for $4 \mathrm{hr}$, and a short-lived return to the low-level activation was observed at $12 \mathrm{hr}$ postpartum, followed by another peak; the latter persisted throughout the first 3 weeks of life. It would seem that the initial activation occurred in response to the stress of birth, e.g., hypoxia and perhaps, sympathetic nerve stimulation. As the effects of delivery wore off, the ratio returned to a low level only to be again elevated; this time the activation presumably occurred in response to a functional stimulation of the tissue by the cold environment. The mother animal usually leaves the nest for the first time at 12 $\mathrm{hr}$ postpartum and the newborn must then activate its mechanisms for nonshivering heat production taking place in brown fat in order to cope with the drop of environmental temperature. Mature animals, after 3 wk of life have developed other means of thermoregulation and nonshivering heat production loses its importance; hence, the observed drop in the brown fat protein kinase activation level.

The relatively high activity ratio observed in white adipose tissue of adult volunteers obtained by the needle biopsy technique most probably reflects catecholamine stimulation occurring as a consequence of a mild, but none the less present, psychologic agitation of the volunteers preceeding the procedure. This is confirmed by the fact that the ratios were lower in the adult tissues collected during surgery procedures when anesthesia was used (Table 1), however, effects of epidural anesthesia on cyclic AMP levels and subsequent protein kinase activity cannot be ruled out.

Total protein kinase activity in pregnant $v s$. nonpregnant women showed no significant differences, but the kinase assayed in the absence of added cyclic AMP was significantly higher in the pregnant group (Table 1). This difference is reflected in the higher activity ratios observed in the pregnant group and may indicate a higher degree of hormonal activation of the adipocytes in this group.

More detailed information on the protein kinase activity ratios will have to be obtained, particularly with different and, perhaps, endogenous proteins as phosphate acceptors, before any definite conclusions can be drawn about the state of activation of the systems involved in the regulation of specific processes.

\section{REFERENCES AND NOTES}

1. Corbin, J. D., Keely, S. L., and Park, C. R.: The distribution and dissociation of cyclic adenosine $3^{\prime} 5^{\prime}$-monophosphate-dependent protein kinase in adipose, cardiac, and other tissues. J. Biol. Chem., 250: 218 (1975).

2. Corbin, J. D., Soderling, T. R., and Park, C. R.: Regulation of adenosine 3'5'monophosphate-dependent protein kinase. I. Preliminary characterization of the adipose tissue enzyme in crude extracts. J. Biol. Chem., 248: 1213 (1973).

3. Glynn, J. M. and Chappell, J. B.: A simple method for the preparation of ${ }^{32} \mathbf{P}$ labelled adenosine triphosphate of high specific activity. Biochem. J., 90: 147 (1964).

4. Hahn, P. and Novak, M.: Development of brown and white adipose tissue. J. 
Lipid Res., 16: 79 (1975).

5. Huttunen, J. K., Steinberg, D., and Mayer, S. E.: ATP-dependent and cyclic AMP-dependent activation of rat adipose tissue lipase by protein kinase from rabbit skeletal muscle. Proc. Natl. Acad. Sci. USA 67: 290 (1970)

6. Knight, B. L. and Skala, J. P.: Protein kinases in brown adipose tissue of developing rats. Electrophoretic separation and assay of soluble protein kinases on polyacrylamide gels and a study of their properties and changes during development. J. Biol. Chem., 252: 5356 (1977).

7. Kuo, J. F.: Changes in relative levels of guanosine-3':5'-monophosphate-dependent and adenosine-3':5'-monophosphate-dependent protein kinases in lung, heart, and brain of developing guinea pigs. Proc. Nat. Acad. Sci. USA, 72: 2256 (1975).

8. Lowry, O. H., Rosebrough, N. J., Farr, A. L., and Randall, R. J.: Protein measurement with folin reagent. J. Biol. Chem., 113: 265 (1957).

9. Melichar, V. and Novak, M.: Einfluss von Adrenalin und Glucagon auf dem Kohlenhydrat - und Fettstoffwechsel bei Neugeborenen. In: G. Joppich and H. Wolf, Metabolism of the Newborn, p. 360-367 (Hippokrates Verlag, Stuttgart, 1970).

10. Novak, M. and Melichar, V.: Technique for sampling of human adipose tissue. Physiol. Bohemoslov., 12: 84 (1963).

11. Novak, M., Melichar, V. and Hahn, P.: Changes in the content and release of glycerol in subcutaneous adipose tissue of newborn infants. Biol. Neonate, 8 : 253 (1965).

12. Novak, M. and Monkus, E.: Metabolism of subcutaneous adipose tissue in the immediate postnatal period of human newborns. 1 . Developmental changes in lipolysis and glycogen content. Pediatr. Res., 6: 73 (1972).

13. Rubin, C. S. and Rosen, O. M.: Protein phosphorylation. Ann. Rev. Biochem., 44: 831 (1975).

14. Soderling, T. R., Corbin, J. D. and Park, C. R.: Regulation of adenosine 3'S'monophosphate-dependent protein kinase. II. Hormonal regulation of the adipose tissue enzyme. J. Biol. Chem., 248: 1822 (1973).

15. Skala, J. P. and Hahn, P.: Changes in interscapular brown adipose tissue of the rat during perinatal and early postnatal development and after cold acclima-

Copyright $\odot 1979$ International Pediatric Research Foundation, Inc. 0031-3998/79/1305-0626\$02.00/0 tion. VI. Effect of hormones and ambient temperature. Int. J. Biochem., 5: 95 (1974).

16. Skala, J. P., Hahn, P. and Drummond, G. I.: A protein kinase inhibitor in brown adipose tissue of developing rats. Biochem. J., 138: 195 (1974)

17. Skala, J. P. and Knight, B. L.: Protein kinases in brown adipose tissue of developing rats. I. GTP as nucleotide substrate for histone phosphorylation. Biochim. Biophys. Acta, 385: 114 (1975).

18. Skala, J. P. and Knight, B. L.: Protein kinases in brown adipose tissue of developing rats. Substrate specificities, separation, and changes in activity during development. Can. J. Biochem. 56: 869 (1978).

19. Skala, J. P. and Knight, B. L.: Protein kinases in brown adipose tissue of developing rats. The state of activation of protein kinase during development and cold exposure and its relationship to adenosine $3^{\prime}: 5^{\prime}$-monophosphate, lipolysis, and heat production. J. Biol. Chem., 252: 1064 (1977).

20. Skala, J., Novak, E., Hahn, P., and Drummond, G. I.: Changes in interscapular brown adipose tissue of the rat during perinatal and early postnatal development and after cold acclimation. V. Adenyl cyclase, cyclic AMP, protein kinase, phosphorylase kinase, phosphorylase and glycogen. Int. J. Biochem., 3: 229 (1972).

21. The authors thank Mrs. Jeanne Cesteros for her assistance in the preparation of this manuscript.

22. This research was supported by NIH grant numbers HD04946 and AM21251 and by the Canadian Medical Research Council, Grant MA-5659 (J. P. S.).

23. This research project was reviewed and approved by the Human Research Committee of the University of Miami School of Medicine. The reason for collecting the sample was always explained to the mothers and the sample was collected only after obtaining written informed consent.

24. Medical Research Council (Canada) Scholar.

25. Requests for reprints should be addressed to: Dr. Paul B. Wieser, Mailman Center for Child Development, P. O. Box 520006, Biscayne Annex, Miami, Florida 33152 USA.

26. Received for publication October 21, 1977.

27. Accepted for publication June 1, 1978 .

Printed in U.S.A. 